ION MANOLESCU

\title{
LITERARY HISTORY AND COGNITIVE SCIENCE. A PSYCHO-NEUROLOGICAL PERSPECTIVE ON ROMANIAN INTERBELLUM FICTION
}

Nowadays, cognitivism is regarded as one of the most innovative means of expanding the boundaries of science, as it opens a significant number of possibilities for interdisciplinary research. Cognitive neurology, cognitive psychology, cognitive philosophy or cognitive linguistics are just a small part of the bigger cognitive picture in which almost every aspect of our life is related to inner, structural theories of the mind and brain. One of these theories, called the computational theory of mind, states that we exist as living computing machines, where the body represents the carcass, the brain acts as the hardware, while the mind, animated by its neuroprograms, plays the part of the software ${ }^{1}$.

Some would argue that the novelty of this theory is questionable, since philosophers like Descartes or fiction writers such as Philip K. Dick have long debated over the issue of mechanical structures and functions existing in living organisms. However, the computational theory of mind enables us to better understand how the electro-chemistry of the brain and the mathematically structured operations of the mind, that is we, perform during complex processes such as perception, representation or decision-making. Combined methods from recent neurology, psychology and computer science, all related to cognitive instruments of research (for instance, helmets with electrodes or magnetic imagery devices, which tell the tale of our inner thoughts or physical reactions in terms of tracking the blood irrigation of our cortical areas or in terms of mapping the trajectory of axons inside our neurosynaptic brain circuitry) allow a more complete exploration of one's behavior, when consciousness is involved.

At this point, my main question is: could we import such methods of investigation from cognitive science and implement them in the field of literature? To what extent and benefit, when it comes to confronting them with the traditional methods which give shape and structure to the history of literature (chronological separation; typological separation; ideological separation)? Could we, for instance, define Romanian Interbellum fiction and the main histories of literature which encompass it by means of the psycho-neurological separation? Ultimately, what would that mean: a selection of authors within a Cognitive History of Literature, whose texts and characters suffer from schizophrenia, paranoia, borderline syndrome, and so on?

\footnotetext{
${ }^{1}$ See, among others, Stephen Michael Kosslyn, Image and Mind, Cambridge, Massachusetts and London, England, Harvard University Press, 1980, pp. 171-72.
} 
From a cognitive perspective, we would have to get inside the novels of Camil Petrescu, Anton Holban or G. Ibrăileanu and place the computer-linked network of electrodes on the heads of Ştefan Gheorghidiu, Sandu or Emil Codrescu, in order to fully understand what is going on in their minds and why their conflicting actions inside their brains and within the frame of $20^{\text {th }}$ century modernist fiction may or may not help their authors come out of the usual histories of literature and embark on a new Psycho-Neurological Encyclopedia of Romanian Fiction.

Despite the fact that they use the traditional frames of historicism, typology and ideology, in order to select authors and works and build hierarchies according to debatable criteria (such as reflecting or rejecting modernist ideology or supporting or undermining moral values within the literary text), some of the main Romanian histories of literature dealing with the Interbellum period do take into account psychology as a factor in content selection and text evaluation. Such is the case with E. Lovinescu's Istoria literaturii române contemporane [History of Contemporary Romanian Literature] (1926-1929) and Nicolae Iorga's Istoria literaturii româneşti contemporane [History of Contemporary Romanian Literature] (1934).

In the fourth part of his history of literature, Evoluţia prozei literare [The Evolution of Literary Prose] (1928), Lovinescu asserts that the value of fiction should be related to two criteria: the evolution from rural to urban literary environments, and the evolution from subjective to objective storytelling ${ }^{2}$. In Lovinescu's view, which blends psychology and narratology within a modernist ideological matrix, a novel and its author are at their best when sticking to these criteria and at their worst when ignoring them. His perspective is similar to that of fiction writer and interdisciplinary theorist Camil Petrescu, who bluntly states in his study Noua structură şi opera lui Marcel Proust [The New Structure and Marcel Proust's Work] (1935) that modern psychology should play the leading part when conceiving literature in the $30^{\text {'s }}$ of the $20^{\text {th }}$ century:

Once we acknowledge that in a given age literature intertwines with contemporary psychology, and once we admit that psychology itself is driven by the psychological explanations favoured by the respective age, then we should even more justifiably assert that literature must be structurally synchronous with contemporary science and philosophy ${ }^{3}$.

${ }^{2}$ E. Lovinescu, Istoria literaturii române contemporane [History of Contemporary Romanian Literature], II, Bucharest, Minerva, 1973, pp. 9-15.

${ }^{3}$ Camil Petrescu, "Noua structură şi opera lui Marcel Proust" ["The New Structure and Marcel Proust's Work"], in Teze şi antiteze. Eseuri alese [Theses and Anti-theses. Selected Essays]. Edition by Aurel Petrescu, Bucharest, Minerva, 1971, p. 4: "Dacă afirmăm că literatura unei epoci este în corelaţie cu psihologia acelei epoci, şi dacă stăruim să arătăm că psihologia însăşi este în funcţie de explicaţia psihologică a timpului, ne reîntoarcem cu şi mai multă îndreptăţire la afirmaţia că o literatură trebuie să fie sincronică structural filosofiei şi ştiinţei ei...”. When not specified otherwise, the English translations from Romanian are mine. 
Understandably, both E. Lovinescu, and Camil Petrescu do not use terms such as neurology or psycho-neurology, in an epoch when, as far as reality description and narrative perception are concerned, literary historians and theorists were more accustomed to hearing Freud and Jung's fictional accounts of the human mind, rather than Einstein or Bohr's quantum theories of space-time which could, eventually, lead to a quantum computational theory of mind, brain and perception. A selection of authors and texts based on the psycho-neurological complexity of network narratives (such as those enriching Camil Petrescu's novels Ultima noapte de dragoste, intîia noapte de război, [The Last Night of Love, the First Night of War], 1930, and Patul lui Procust [The Bed of Procrustes], 1933) or on the psychoneurological diversity of the characters' brain-mind dysfunctions (Sandu in Anton Holban's novel Ioana, 1934, or Emil Codrescu, in G. Ibrăileanu's novel Adela, 1933) might have proven decisive for a Cognitive History of Literature, still involving Lovinescu's theories.

However, E. Lovinescu's example of neglecting the importance of the psychoneurological criterion in the selection and evaluation of literary works can hardly be compared to Nicolae Iorga's utter and complete misuse of psychology in his 1934 literary history. Istoria literaturii româneşti contemporane rejects any attempts by Romanian modernist authors to use psychology in their works, while applauding the insertion of moral values in fiction by traditional authors. In Iorga's view, content selection and value attribution are both dependent on one single criterion: the presence or absence of ethics within the literary text. The peak of Nicolae Iorga's misjudgment can be found in his vituperating pages on naturalist, Zola-inspired fiction writer Liviu Rebreanu, nowadays considered the founder of Romanian literary realism. This is how Rebreanu's novel Ion (1920), a masterpiece of hard realism, is depicted by Iorga:

The eighty-character novel, replete with rapes, murders, and all displays of the most primitive instincts whose crude depiction resembles shaking a rotten corpse's leg, relies on the same realism of raw authenticity: the lowest parts of our race's animal life, which the author seems to have glimpsed in some wretched corner of Transylvania, are exhibited here like the testimony of a hopeless inferiority, in the cold style of a constable who is merely taking note of the ignominous deeds that occurred in his district. Slavici's mellow Transylvania, or Mr. Agârbiceanu's strongly ethical vision of the same land, are dismantled, in order to reveal the unbearable dirt, and all the fatalities that are supposedly lying underneath. This recalls the stench exuded from Zola's La Terre, which narrates a similar story of basic passions, in the same vein of moral numbness, yet in higher artistic terms ${ }^{4}$.

\footnotetext{
${ }^{4}$ N. Iorga, Istoria literaturii românești, II: În căutarea fondului (1890-1934) [The History of Romanian Literature, II: In Search of the Substance]. Edition coordinated, notes and index by Rodica Rotaru. Preface by Ion Rotaru, Bucharest, Minerva, 1986, p. 326: „În romanul cu optzeci de personagii, $\mathrm{cu}$ violuri şi omoruri, cu toate manifestaţiile brutei, prezintate crud, ca un cadavru putred pe care 1-ar scutura cineva de un picior, e acelaşi realism de o sălbatecă autenticitate: ce e mai josnic
} 
Emblematic for the perspective of a traditionalist historian of literature, whose titles of chapters look like epic battles against preposterous enemies ("Lupta cu modernismul" ["The Battle with Modernism"] or "Împrăştierea puterilor tineretului" ["The Scattered Strenghts of the Youth"]), Iorga's moral devaluation of Liviu Rebreanu's novel shows a complete misunderstanding of the psychological qualities involved in the realistic depiction of situations and characters and in the naturalistic perspective of storytelling. These precise qualities, which Iorga ignores or condemns, provide value to Rebreanu's novels, turning them into textbook examples of Romanian objective hard realism.

However, when it comes to screening the titles of chapters in literary histories concerning the Romanian Interbellum period, Nicolae Iorga is not the only author to surprise the reader with what we might call "an excessive use of ideological force". E. Lovinescu also choses titles which illustrate his parti-pris for modernism (for instance, "Contribuţia modernistă a Sburătorului" ["The Sburătorul Circle's Contribution to Modernism"]), in an attempt to prove that the very literary current he supports provides the most significant basis for literary selection. ${ }^{5}$

On the other hand, G. Călinescu, in his Istoria literaturii române de la origini pînă în prezent [History of Romanian Literature from its Origins to the Present] (1941), avoids taking sides in the ideological dispute traditionalism $v s$. modernism. His criteria of content selection and text evaluation are related to historicism and typology, in a mix that sometimes seems close to the field of psychology, yet without clearly stating it. Titles of chapters such as "Romancierii 1920-1930", "Romanul gloatei", "Romanul copilăriei", "Proustienii" or "Noua generaţie", "Momentul 1933. Filozofia 'neliniștii' și a 'aventurii'", "Literatura experiențelor" ["The 1920-1930 Novelists", "The Mob Novel", "The Childhood Novel", "Proustian Writers" or "The New Generation". "The 1933 Moment. The Philosophy of 'Unrest' and of 'Adventure", "The Literature of Experiences"] seem closer to a psycho-neurological investigation of Interbellum fiction, as part of a possible cognitive project of reshaping and rewriting literary history ${ }^{6}$.

The closest to such a challenging project is Ovid. S. Crohmălniceanu, in his Literatura română între cele două războaie mondiale [Romanian Literature between the Two World Wars] (vol. I, 1972). Terms such as "automatisms",

\footnotetext{
în viaţa animalică a rasei, cum i se pare autorului că a văzut-o în cine ştie ce colţ blăstămat de Ardeal, se expune aici ca un testimoniu de iremediabilă inferioaritate, într-un rece stil de jandarm care constată infamiile petrecute în raionul său. Ardealul cuminte al lui Slavici, cel de o înaltă valoare etică al d-lui Agârbiceanu sînt spintecate ca să se vadă nespusa mizerie ce ar fi înlăuntru, cu toate fatalităţile sale. E ca duhoarea care se desface din La Terre a lui Zola, povestea aceloraşi patimi elementare, prezintată însă acolo cu altă artă, deşi cu aceeaşi indiferenţă morală".

5 E. Lovinescu, Istoria literaturii române contemporane [History of Contemporary Romanian Literature], I, Bucharest, Minerva, 1973, p. 651.

${ }^{6}$ See G. Călinescu, Istoria literaturii române de la origini pînă în prezent [History of Romanian Literature from its Origins to the Present]. Edition by Al. Piru, Bucharest, Minerva, 1982, pp. 10571058.
} 
"psychological analysis", "obsessive projections" are to be found in titles of chapters that testify to the author's preference for the use of psychology and psychoanalysis in attributing significance and value to Romanian Interbellum fiction: "Comedia automatismelor", "Analiza psihologică", "Universul proiecţiilor obsessive" ["The Automatisms Comedy", "The Psychological Analysis", "The Universe of Obsessive Projections"] and even "Literatura 'autenticităţii' şi 'experienţei" ["Literature of 'Authenticity' and 'Experience"'] - which is quite similar, in content selection criteria, to G. Călinescu's "Literatura experienţelor" ["The Literature of Experiences"]. ${ }^{7}$

Let us see now to what extent a psycho-neurological perspective, based on recent evolutions in cognitive science, may prove useful to finding new meanings and, consequently, new values in Romanian Interbellum fiction. Camil Petrescu's characters Ştefan Gheorghidiu (in Ultima noapte de dragoste, întâia noapte de război) and Fred Vasilescu (in Patul lui Procust) are perfect examples of mindbrain conflicts and, possibly, defective cortical electro-chemical nanowiring. In the thirties, Henri Bergson's psychological theories on time elapsing and time simultaneity or Edmund Husserl's philosophical courses on the phenomenon of consciousness and inner time were already pre-neurological warnings that, inside one's head, things are never what they seem to be.

Obsessively jealous of his wife, whom he suspects of cheating on him, Ştefan Gheorghidiu, a modern, self-centered intellectual from the first decades of the $20^{\text {th }}$ century, reacts to his painful doubts in the most astonishing way. He simply rewards Ela for her constant, yet never proven, infidelities: "I must write the donation letter this very evening" ${ }^{\prime}$. Or:

I gave my wife for the second time the same sum of money she asked for when we were in Cîmpulung, and I inquired what were the formal procedures for gifting her [my underlining, I.M.] the Constanța houses. I told her she could have absolutely everything that was in the house, from valuable objects, to books... from personal items, to memories ${ }^{9}$.

Vanity? Financial masochism? Stockholm syndrome reactions, indicating gender submission to the psychologically dominant Alpha female? None of these explanations seem to fully encompass the contradictory behavior of our devastated, still highly grateful hero. Perhaps Gheorghidiu's actions are best understood if we take into account the conflict between the rational programs of the mind and the

7 See Ov. S. Crohmălniceanu, Literatura română între cele două războaie mondiale [Romanian Literature between the Two World Wars], I, Bucharest, Minerva, 1972, p. 662.

${ }^{8}$ Camil Petrescu, Ultima noapte de dragoste, întâia noapte de război [The Last Night of Love, the First Night of War]. Preface by Paul Georgescu, Bucharest, Editura pentru Literatură, 1965, p. 45: "Trebuie să fac chiar în astă seară scrisoarea de donație...".

${ }^{9}$ Ibidem, p. 206: „I-am dăruit nevestii-mi încă o sumă ca aceea cerută de ea la Cîmpulung şi m-am interesat să văd cu ce formalitate îi pot dărui [sublinierea mea, I.M.] casele de la Constanţa. I-am spus că-i las absolut tot ce e în casă, de la obiecte de preț la cărţi... de la lucruri personale, la amintiri." 
uncontrollable activities of the brain. Although Camil Petrescu's character solemnly states that he hates his wife for her supposed infidelities (the executable of duty, inside the software of traditional, unbreakable marriage, kicks in here), he is dependent on her affairs, in order to feel alive (the dopaminergic circuit of the brain, which rewards him with a flow of pleasure hormones, may get activated as a response to Ela's powerful flirtation signals): "Full of gratitude, I was telling myself that woman deserved any kind of sacrifice" $"$.

In a way similar to Gheorghidiu's, in Patul lui Procust, Fred Vasilescu, Camil Petrescu's other main male character, rewards doamna T, one of his mistresses who causes him quite some trouble, as he is so attracted to her intellect, that he feels the need to abruptly end their relationship, by leaving her everything he owned, after his death: "She left behind quite a considerable fortune: a plane, the car, the race horses, a large strip of land near the city"

This is the same Fred Vasilescu who, apparently, could not and would not allow any woman step on his freedom: "I realized how much I had let that paralysing daily surrendering drag me out... The whole situation could only be redeemed by some kind of desperate gesture"" 2 . And, further on: "- Madam, I think you are making a confusion... I treasure immensely your intelligence... and I enjoy your presence ... but as a woman, I am just not into you" 13 .

The character's "stupid contradictions", to quote his own words, may be explained via a precise scientific examination of his brain, in terms of magnetically scanning Vasilescu's cortical and sub cortical activity: perhaps, inside his brain, the blood irrigation of the physical pleasure area is connected to that of the moral duty area? To do something right to somebody who is not necessarily the right person for you may prove the only way to obtain dopamine and serotonin, inside a body accustomed to adrenaline rushes (let us not forget that Fred Vasilescu is a sportsman, keen on flying small planes and riding automobiles at the edge of risk)?

Contradictions also arise in Anton Holban's novels, centered on the individual's mental inability to pinpoint the nature of reality, especially when it comes to human relationships. Sandu, the main character in the novel Ioana (1934), a young intellectual keen on reading Racine and listening to classical music, is incapable of perceiving his lover, Ioana, in a coherent, satisfactory way: she is either "a strange beauty", or ugly as "a goose", while her dresses, on some

${ }^{10}$ Ibidem, p. 251: "Mă gîndeam, cu recunoştinţă, că femeia aceasta merită toate sacrificiile din lume".

${ }^{11}$ Camil Petrescu, Patul lui Procust [The Bed of Procrustes]. Preface and chronology by Constantin Cubleșan, Bucharest, Minerva, 1982, p. 320: „Averea pe care a lăsat-o e destul de mare: un avion, automobilul, caii de curse, un teren mare în apropierea oraşului".

12 Ibidem, p. 230: "Mi-am dat seama cât de mult mă lăsasem târât de această paralizantă cedare din fiecare zi... Numai un gest disperat putea restabili situaţia...".

13 Ibidem, p. 231: „,- Doamnă, cred că faceţi o confuzie... Vă preţuiesc nesfîrşit de mult ca inteligenţă... şi-mi place prezenţa dumneavoastră... dar nu mă interesaţi ca femeie”. 
occasions, look "attractive", and on other seem to show "no taste at all"14. Could Anton Holban's character suffer from severe mental conditions, such as those described by neurologist Oliver Sacks in his book The Man Who Mistook His Wife for a Hat (1985) ? ${ }^{15}$ Could Sandu have some kind of a brain damage, so as to see conflicting realities simultaneously? Or is he simply a fraud, an astute "soft actor" who simulates psycho-neurological disorders, in order to gain attention from Ioana and keep her close to him?

The idea does not seem too far-fetched, should we take into account the behavior of Anton Holban's other self-centered, contradictory character, also named Sandu, in the novel Jocurile Daniei [Dania's Games] (1937). This particular Sandu is also helpless in understanding human relationships, but, still, has the ability to alter reality, by means of neurological shape shiftings: Ioanid Park, in Bucharest, looks "pale yellow" because of his anger, while it changes to "fiery red", as he relaxes ${ }^{16}$. On such occasions, Sandu's changing moods, directly related to his fluctuating brain activity, create a false experience of what is going on in the external world. To put it in neurologist Chris Frith's words, Sandu may experience an "electro-neural dysfunction" in his brain, which generates a mistaken image of reality and sends it to his mind, persuading it to be true - the so-called "false knowledge" of the physical world ${ }^{17}$.

Finally, let us turn to the strange case of Dr. Emil Codrescu, in G. Ibrăileanu's novel Adela (1933), a Romanian Lolita, published 20 years before Nabokov's novel. Also a hyper-analytical, self-centered intellectual, very similar, in his monomania, to Gheorghidiu and Sandu, Emil Codrescu embarks on a mental trip to happiness with a woman 20 years younger than him, whom he knows from her childhood. Codrescu loves Adela desperately, yet he never shares his intense feelings with her; he is always charming and affectionate, still without trying to physically seduce her. However, not to seduce somebody does not mean to ignore that person or to avoid meeting him or her. On the contrary, it means exactly the opposite, especially when your mind (and not your words or your actions) does the whole job for you: "It was Adela who told me that I loved her: 'I knew you would come to see me in the morning', can not have another meaning. What happened today is all clear: Adela encourages me - by no means does she try to defend herself..."18.

\footnotetext{
${ }^{14}$ Anton Holban, O moarte care nu dovedeşte nimic. Ioana [A Death that Proves Nothing. Ioana]. Edition by Petru Livius Bercea, Timişoara, Editura de Vest, 1993, p. 105.

${ }^{15}$ Oliver Sacks, The Man Who Mistook His Wife for a Hat, London, Picador, 2011, p. 9-24.

${ }^{16}$ Anton Holban, Opere 1 [Works 1]. Edition by Elena Beram, Bucharest, Minerva, 1997, p. 371.

${ }_{17}$ Chris Frith, Making up the Mind. How the Brain Creates our Mental World, Oxford, Blackwell, 2009 , p. 36.

${ }^{18}$ G. Ibrăileanu, Adela. Postface by Eugenia Tudor-Anton, Bucharest, Minerva, 1976, p. 74: „Adela mi-a spus că o iubesc: „Ştiam că ai să vii dimineața la mine” nu poate avea alt înţeles. Tot ce s-a petrecut azi e clar: Adela mă încurajează - în nici un caz nu se apără..."
} 
In terms of mistaking one's thoughts and wishes for reality, Codrescu's words resemble the words of Romanian sports commentator Teoharie Coca-Cosma during the penalty shoot-out at the end of the Barcelona-Steaua Bucureşti final of the European Champions Cup in 1986: the sentences Adela loves me. Adela must love me! look strangely similar to Lăcătuş trebuie să înscrie! Lăcătuş va înscrie! [Lăcătuș must score! Lăcătuș will score!] (which he did).

Contradictions, mind-brain conflicts, false knowledge of reality, based on mistaken suppositions - all, in the novel Adela, are illustrative of the constant psycho-neurological texture of the narrative, which the author, despite his not mentioning it directly, seems quite found of: "cerebral hypertrophy", "hallucinations and ghosts" (in the mind), "smoke on the brain" and "superstructures" (of the brain?) are just some of the expressions used by Ibrăileanu's first person narrator ${ }^{19}$.

Such examples help us speculate that recent discoveries in cognitive science may profit the study of literature, since they enrich the significations of fictional texts and refresh the canonic status of their authors. Rereading Romanian Interbellum fiction and rewriting literary history via postmodern interdisciplinary means (such as the blending of psychology, neurology and aesthetics) seems, at present, a tough challenge both to literary historians and to the general public. However, as neurotechnology becomes more and more accurate, as we go deeper into the realm of cyberknowledge and cyberperception, the results of such an endeavor may prove surprisingly fruitful to the field of humanities.

\section{BIBLIOGRAPHY}

CĂLINESCU, G., Istoria literaturii române de la origini pînă în prezent [History of Romanian Literature from its Origins to the Present]. Edition by Al. Piru, Bucharest, Minerva, 1982.

CROHMĂLNICEANU, Ov. S., Literatura română intre cele două războaie mondiale [Romanian Literature between the Two World Wars], I, Bucharest, Minerva, 1972.

FRITH, Chris, Making up the Mind. How the Brain Creates our Mental World, Oxford, Blackwell, 2009.

HOLBAN, Anton, O moarte care nu dovedeşte nimic. Ioana [A Death that Proves Nothing. Ioana]. Edition by Petru Livius Bercea, Timişoara, Editura de Vest, 1993.

HOLBAN, Anton, Opere 1 [Works 1]. Edition by Elena Beram, Bucharest, Minerva, 1997.

IBRĂILEANU, G., Adela. Postface by Eugenia Tudor-Anton, Bucharest, Minerva, 1976.

IORGA, N., Istoria literaturii românești, II: În căutarea fondului (1890-1934) [The History of Romanian Literature, II: In Search of the Substance]. Edition coordinated, notes and index by Rodica Rotaru. Preface by Ion Rotaru, Bucharest, Minerva, 1986.

KOSSLYN, Stephen Michael, Image and Mind, Cambridge, Massachusetts and London, England, Harvard University Press, 1980.

${ }^{19}$ Ibidem, pp. 145-146. 
LOVINESCU, E., Istoria literaturii române contemporane [History of Contemporary Romanian Literature], I, Bucharest, Minerva, 1973.

PETRESCU, Camil, "Noua structură şi opera lui Marcel Proust" ["The New Structure and Marcel Proust's Work"], in Teze şi antiteze. Eseuri alese [Theses and Anti-theses. Selected Essays]. Edition by Aurel Petrescu, Bucharest, Minerva, 1971, pp. 3-37.

PETRESCU, Camil, Patul lui Procust [The Bed of Procrustes]. Preface and chronology by Constantin Cubleșan, Bucharest, Minerva, 1982.

PETRESCU, Camil, Ultima noapte de dragoste, întâia noapte de război [The Last Night of Love, the First Night of War]. Preface by Paul Georgescu, Bucharest, Editura pentru Literatură, 1965.

SACKS, Oliver, The Man Who Mistook His Wife for a Hat, London, Picador, 2011.

\section{LITERARY HISTORY AND COGNITIVE SCIENCE. A PSYCHO- NEUROLOGICAL PERSPECTIVE ON ROMANIAN INTERBELLUM FICTION \\ (Abstract)}

In the $21^{\text {st }}$ century, literary history can no longer be perceived as an autonomous, monolithic discipline. To what extent is it open to structural and methodological influences from non-literary disciplines, such as cognitive science? In terms of content selection and value attribution, what would the benefits of connecting literary history and cognitive neurology and psychology be? The aim of my study is to provide answers to these questions, while rereading the works of $20^{\text {th }}$ century Romanian novelists (Camil Petrescu, Anton Holban, G. Ibrăileanu) and authors of literary histories (E. Lovinescu, N. Iorga, G. Călinescu) from a neuroscience perspective.

Keywords: literary history, cognitivism, modernism, neuroscience, Romanian fiction, interdisciplinarity.

\section{ISTORIA LITERARĂ ȘI ȘTIINȚELE COGNITIVE. O PERSPECTIVĂ PSIHO- NEUROLOGICĂ ASUSPRA ROMANULUI ROMÂNESC INTERBELIC (Rezumat)}

În secolul al XXI-lea, istoria literară nu mai poate fi percepută ca o disciplină autonomă, monolitică. În ce măsură este ea totuși deschisă influențelor structurale și metodologice provenite din sfera disciplinelor ne-literare, precum științele cognitive? Care ar putea fi beneficiile corelării istoriei literare cu psihologia sau neurologia cognitivă în ceea ce privește selecția conținuturilor și atribuirea valorilor? Scopul studiului meu este să răspundă acestor întrebări prin recitirea dintr-o perspectivă neuroștiințifică a operei unor romancieri (Camil Petrescu, Anton Holban, G. Ibrăileanu) și istorici literari (E. Lovinescu, N. Iorga, G. Călinescu) de secol XX.

Cuvinte-cheie: istorie literară, cognitivism, modernism, neuroștiință, roman românesc, interdisciplinaritate. 